\title{
Serum Protein
}

National Cancer Institute

\section{Source}

National Cancer Institute. Serum Protein. NCI Thesaurus. Code C17126.

Dissolved proteins of blood plasma. These mainly consist of albumins and globulins and include antibodies and blood-clotting proteins. 